\title{
Reviews on land use change induced effects on regional hydrological ecosystem services for integrated water resources management
}

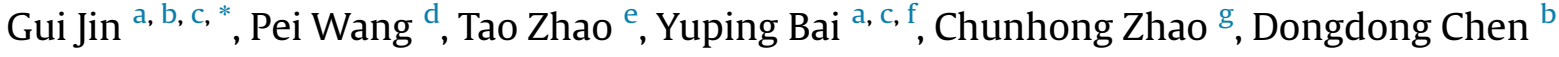 \\ a Institute of Geographic Sciences and Natural Resources Research, Chinese Academy of Sciences, Beijing, 100101, China \\ ${ }^{\mathrm{b}}$ Faculty of Resources and Environmental Science, Hubei University, Wuhan, Hubei, 430062, China \\ c Center for Chinese Agricultural Policy, Chinese Academy of Sciences, Beijing, 100101, China \\ ' Zhongnan University of Economics and Law, Wuhan, 430073, China \\ e Bureau of Science and Technology for Development, Chinese Academy of Sciences, Beijing, 100864, China \\ ${ }^{\mathrm{f}}$ University of Chinese Academy of Sciences, Chinese Academy of Sciences, Beijing, 100049, China \\ ${ }^{g}$ Department of Geography, Texas State University, San Marcos, TX, 78666, USA
}

\section{A R T I C L E I N F O}

\section{Article history:}

Received 1 September 2015

Received in revised form

6 October 2015

Accepted 11 October 2015

Available online 23 October 2015

Keywords:

Land use change

Regional hydrological ecosystem services

Integrated water resources management Review

\begin{abstract}
A B S T R A C T
This paper proposed to provide valuable information for integrated water resources management through evaluating the research on the interaction mechanism among land use changes, regional hydrological ecosystem services and human well-being. Firstly, the driving mechanism of land use and land cover changes was introduced in this paper. Secondly, the overview of the interaction mechanism among land use and land cover changes, regional hydrological ecosystem services and human well-being was given. Based on the meta-analysis, land use changes have a profound influence on regional hydrological ecosystem services, and the variation of hydrological ecosystem could benefit or impair human wellbeing. Finally, two suggestions were emphasized for managers or policy makers for the future integrated water resources management: (1) Proper land use makes for the water resource management; (2) Blindly pursuing the provisioning services weakens other services of hydrological ecosystem.
\end{abstract}

() 2015 Elsevier Ltd. All rights reserved.

\section{Introduction}

There is growing concern that water crisis caused by human activities is severely threatening human survival and impairing the law of nature (Schindler and Donahue, 2006; Bakker, 2012). It poses challenges on managers or policy makers for developing scientific and proper plans for preserving water resources or saving water use and leads to the recognition that the management of water resources requires a holistic approach. Integrated water resources management (IWRM), an empirical concept built up from the onthe-ground experience of practitioners, is now the dominant paradigm for relieving the water-related issues (Calizaya et al., 2010). The UN provided the most-quoted definition (1992): a process to promote the coordinated development and management of water, land and related resources, in order to maximize the resultant economic and social welfare in an equitable manner without

\footnotetext{
* Corresponding author. Institute of Geographic Sciences and Natural Resources Research, Chinese Academy of Sciences, Beijing, 100101, China.

E-mail address: jing_simlab@163.com (G. Jin).
}

compromising the sustainability of vital ecosystems. Therefore, IWRM can be enhanced through water resource modeling and land use planning. With the exploration on the interconnections between Land Use and Land Cover Changes (LUCC) and regional hydrological ecosystem services or water-land coupling system, the solutions for improving water environment are no longer limited to study water itself, and the research on the interaction mechanism of LUCC and hydrological ecosystem services could offer another accessible path for integrated water resources management.

The dynamics of LUCC and their resulting consequences are one of the central themes of global change research (Lambin et al., 2001; Turner et al., 2007). With the development of theory and methodology of the dynamics of land system change and the establishment of the Global Land Project (Liu et al., 2014), researchers have increasingly realized the close relationships among natural environmental evolution, terrestrial ecosystem processes, human production activities and the dynamics of LUCC (Deng et al., 2014). LUCC considered as an important driving force for the hydrological ecosystem change, enormously alters the structure of the earth surface system as well as its material and energy flows. In the past decades, aside from the study on the process and driving 
mechanism of LUCC at different spatial scales, the investigation upon the externality of LUCC, especially the effects of land use changes on regional hydrological ecosystem services, was another hotspot, due to the awareness of water as an increasingly scarce yet essential resource for sustainable development (Wu et al., 2014). As the enhanced land use intensity and growing land cover diversity dramatically varies the biogeochemical circulation, hydrological process and landscape of the earth surface, these variations affect the status, characteristics and functions of the regional hydrological ecosystem (Deng et al., 2013a).

The Millennium Ecosystem Assessment (MA) synthesizes and analyzes the theory and methodology of ecosystem services framework, and makes plenty efforts to illustrate its widespread importance and strengthen recognition and knowledge of societal dependence on ecosystems (Van Kamp et al., 2003; Pejchar and Mooney, 2009; Smith et al., 2013). Hydrological ecosystem services are just one category of diverse services providing tremendous beneficial interests for people. As human well-being varies with ecosystem services change reported by Intergovernmental Science-Policy Platform on Biodiversity and Ecosystem Service (IPBES) in 21st century, hydrological ecosystem services involving freshwater supply, spiritual uses and flood damages have both negative and positive impacts on human-well-being. Thus, the IWRM is required to governance the consequences induced by alteration of hydrological ecosystem services for optimizing the human benefits. Of course, there is a large amount of evidences to clarify the internal and external mechanism of the changes of hydrological ecosystem services for integrated water resources management (Daily and Matson, 2008; Polasky and Segerson, 2009; Gascoigne et al., 2011).

What is the driving mechanism of dynamics of LUCC in terms of natural conditions and socio-economy? How does the LUCC act on regional hydrological ecosystem services? What are the impacts of regional hydrological ecosystem services on human well-being? And how does the IWRM do to improve the human well-being based on the effects of LUCC upon hydrological ecosystem services? This paper gives the answers in tandem with an investigation on the interaction among LUCC, regional hydrological ecosystem services and human well-being. Then the remainder will introduce the IWRM through land use regulating in the context of research on the impacts of LUCC on hydrological ecosystem services. Last but not least, conclusions and expectations of relevant study on LUCC and regional hydrological ecosystem services and IWRM - will be given.

\section{Driving mechanism of LUCC}

The analysis on driving forces of LUCC is one of the vital contents for LUCC research (Singh and Shi, 2014), their relationship is often quantified by combining use conceptual model and mathematical model, introducing mathematical statistics methods and adopting the historical and current LUCC data (Deng et al., 2013b). The drivers of LUCC are usually divided into two major categories: natural factors and socioeconomic factors (Weng, 2002). Naveh (1995), Crow et al. (1999), Veldkamp and Verburg (2004) and Huang et al. (2007) made multiple efforts to identify the natural elements of LUCC. Natural factors often refer to natural and environmental characteristics, climate change, soil condition, vegetation succession, periodic interference, and other natural processes (Wu et al., 2013). Millette et al. (1995) and Zhen et al. (2014) made achievements on socio-economic elements. As the report of International Geosphere-Biosphere Program (IGBP) and International Human Dimensions Programme on Global Environmental Change (IHDP) stated (Xu et al., 2013), socio-economic elements include demographic change, poverty status, technological progress, economic growth, political and economic structure, and core value of the society. However, the main driving force remains uncertain due to the variation of regional characteristics.

\subsection{Natural factors of LUCC}

First and foremost, the differences of natural conditions determine regional heterogeneity of the LUCC in spatial and temporal, containing the heterogeneity of land suitability, natural structure of LUCC and natural condition of land system (Li et al., 2013). In the long run, the physical elements provide basic condition for LUCC, especially geology, geomorphology and soil. Except for the human activities, organism and water resource are the components of the land and also drives the natural dynamics of land through the phenomena of surface erosion, transportation and deposition acting on the formation of the land. In the natural system, climate change is usually considered as the main driver of LUCC, and their relationship is complex. Recently, the popular method is to assess the effects of future climate change on LUCC by using an economic model based on exogenous environment variables. The fourth assessment report released by Intergovernmental Panel on Climate Change (IPCC) in 2007 presented that climate change induced by human activities would bring adverse effects on society, economy and environment, even alter the way of land using, in light of the prediction for the changes of global temperature, sea level and snow cover in the next 100 years by different models. According to the results of the simulation and prediction for LUCC in different climate scenarios, land use types vary with climate change in different typical regions, such as the urbanization region and the afforestation region.

\subsection{Socio-economic factors of LUCC}

Socio-economic factors of LUCC are land demand, land investment, urbanization, land use intensity, land ownership, land privatization, population, technology, economic growth, policy, core value of the society, etc. The relevant research established index system for LUCC and constructed LUCC model considering the coupling characteristics of LUCC model and other global environmental change models to simulate and predict the dynamics of LUCC (Li et al., 2013). With the advances of global urbanization, growth of population, and boom of agricultural activity and industrialization, artificial influences cannot be ignored. Based on the future socio-economic development conditions and national policies of China, Deng et al. (2008) set up three scenarios, namely Usual scenario, Rapid Economic Growth scenario and Cooperate Environmental Sustainability scenario, to simulate the spatial structure of LUCC in 2005-2010 taking natural factors and socioeconomic factors into account by adopting Global Change Assessment Model (GCAM), and utilized Dynamics of Land System (DLS) to analyze the future land use change in spatial and temporal in China. Several international case studies also revealed an intricate relationship between population and LUCC (Lin et al., 2014), which implies that it is not linear dependence due to the large regional differences and temporal variation. Thus, it is necessary to comprehensively understand the driving mechanism of LUCC in global range and carry on the research by conducting the case studies for comparative analysis (Lambin and Geist, 2001).

Due to heterogeneity of the way and the consequences of these factors acting on LUCC, we treat all these factors as a whole to simplified their sophisticated relationships, and reveal the processes and the evolution of inherent forces of LUCC via the research on structure, function and the material/energy flows of LUCC (Wu et al., 2014). Therefore, the research on driving mechanism of LUCC increasingly involved the integrated apply of natural and social sciences. 


\section{Effects of LUCC on regional hydrological ecosystem services}

\subsection{Hydrological ecosystem services}

Human has access to direct and indirect streams of benefits generated by hydrological ecosystem services, the final outputs of ecosystem functions or processes, in the following main categories (Tognetti et al., 2006). They are organized into following broad categories:

Hydrological provisioning services, often referred to the services by using the term "watershed services" emphasizing the utilization of the concept in the set of integrated water resources management (Smith et al., 2006), are deemed as one of a bundle of essential services-like air quality, carbon dioxide sequestration, and soil generation-provided by ecosystems which are interrelated in dynamic and complex ways. The hydrological ecosystem efficiently acts on flow regulation and filtration, crucial aspects of which involve the control of mean surface runoff, peak or flood flows, base or dry season flow, and erosion and sediment load, as well as recharge of groundwater and soil moisture (Rockstrom, 2000). These services maintain water quality, as well as mangroves, estuaries, and coastal zone processes. Also, they control the level of groundwater tables that may have adverse effects on agriculture and have benefits on water storage. Apart from these provisioning and regulating services, those that maintain natural flow and disturbance regimes as drivers of ecosystem evolutions which support aquatic ecosystem resilience refer to hydrological supporting services. Besides, some services could also support cultural values, for instance aesthetic qualities could support tourism and recreational uses. Peterson et al. (2003) stated that with the increasing number of buildings along the Northern Highlands Lake District of Wisconsin during the past 30 years, exploitation of lake contributed to coastal economic growth and strengthened the lake's cultural services. In contrast, the changes of vegetation coverage along the lake aggravated subsidence, deteriorated fish habitats and fishing industry, which directly weakened a bundle of provisioning services. In addition, the regulating services decline with the worsening water quality.

The above findings indicate that balanced growth among hydrological ecosystem services is optimum, or other services will degrade if human blindly pursue the provisioning services. Moreover, it will endanger the benefits of contemporary and next generations. Therefore, all kinds of ecosystem services make for human life, and it is sustainable to keep balance of each ecosystem services.

\subsection{Effects of LUCC on regional hydrological ecosystem services}

In order to promote socioeconomic development, humans change the way of land using and the management methods to improve the living standard, which also alters regional hydrological ecosystem services to some extent. LUCC often leads to the variation of regional hydrological ecosystem services, which on one hand reflected the hydrological characteristic of land surface as the changes of some physical attributes of the regional land surface involving roughness, albedo, soil moisture, etc. can trigger the climate change. On the other hand, hydrological ecosystem services change can veer from the earth's surface water circulation and then alter the water exchange between land surface and the atmosphere, between soil and plant (Lin and Lin, 2014).

From a macroscopic view, there is a close relationship between structures and functions of hydrological ecosystems among material, energy value and information transformation between human and land. From the microscopic view, the natural components of the hydrological ecosystem and their interactions also can profoundly impact the distribution of regional land resources as well as its development and utilization mode. Specifically, the effects of land use on hydrological ecosystem services embody in three aspects. First, there is a difference between the main hydrological ecosystem services produced by different land use types. Second, land use pattern change has a significant impact on the hydrological ecosystem service. Third, the effect of LUCC on hydrological ecosystem services differs with the varying land use intensity (Bolund and Hunhammar, 1999). And the effect can be positive or negative. Therefore, it is urging to enhance the understanding of the hydrological ecosystems for human by the research of developing the theoretical framework and mathematical model containing the assessment of hydrological ecosystem services and natural capital value (Deng et al., 2010).

(1) The effect of LUCC on the hydrological provisioning services. The hydrological ecosystem continuously provides sufficient clean water for the human society, which serves as the basis of human survival. The UN Food and Agriculture Organization (FAO) studied in African found that agricultural production activities significantly interfered with the water conservation and nutrient balance of soil during 1982-1984, and the consequences were more serious in some countries as the soil nutrients and soil water were almost exhausted (Smaling and Fresco, 1993). Another case study of the Rouge River Basin in southwest Michigan in US showed that the land use changes, especially the industrialization, completed the heavy metal pollutant and organic chemicals to be discharged into underground. The shallow aquifers and the water of Rouge River were contaminated (Murray and Rogers, 1999). The surplus of nitrogen and phosphorus from agricultural production brings about water quality deterioration, oxygen depletion, death of fish, algae bloom, and epidemic of water-borne diseases (Carpenter et al., 1998; Bennett et al., 2001; Townsend et al., 2003). The transformation of land use types responded to the changes of hydrological provisioning services.

(2) The effect of LUCC on the hydrological regulating services. The regulating services of hydrological ecosystem include water conservation, flood control, and water purification, etc. The dynamics of vegetation type, area and quantity induced by LUCC break the regional balance of water resource and hamper the reaction capacity for environmental change controlled by the main vegetation structure. The research on urbanization indicates that rural land is greatly reduced because of urbanization construction. According to the obvious correlation between mainly water-quality index and land-use type, it shows that land use change resulted from urbanization greatly influences water resources supply and demand balance (Shi et al., 2014a,b).

(3) The effect of LUCC on the hydrological supporting services. The hydrological supporting services involve the maintenance of natural flow and disturbance regimes which support aquatic ecosystem resilience. Each hydrological ecosystem service corresponds to different land use type. On one hand, LUCC can alter the physiochemical characteristics on land surface and change the hydrological ecosystem, thus influence the regional hydrological cycle as well as the whole biochemical process. On the other hand, the hydrological ecosystem supports LUCC with soil water balance. One research on the wetland around the Trichonis Lake in Greece shows that climate slightly influences the changes of wetland, while LUCC plays the leading role in the wetland change (Dimitriou and Zacharias, 2010). 
(4) The influence of LUCC on the water-related cultural services. The water-related cultural services mainly include the spiritual and religious values, recreation and ecotourism, aesthetic value, incentive function, education function, social function, cultural inheritance, cultural diversity, and knowledge system. Some of them are tangible and visually identifiable, while others are invisible and expressed by human activities (Pleasant et al., 2014). The research in Malagasy reveals that there is a correlation between the ecosystem service and the cultural heritage value caused by the mobility of local fishermen. The relevant analysis can offer preserving measures for the local cultural heritage (Oleson et al., 2015). The cultural services of ecosystem can be improved by proper land use planning like the construction of school and park.

\section{Effects of regional hydrological ecosystem services on human well-being}

Human survival and sustainable development depends on the freshwater provisioned by hydrological ecosystem services (Delgado et al., 2013). And it is varying due to the fact that it encompassed by a fluctuating external environment, which implies that changes of hydrological ecosystem services could be for or against human well-being. However, Kremen et al. (2000) and McConnell (2002) proposed that the overall impacts of ecosystem services on human well-being cannot be determined by the research in one region or modeling through using shortterm data. Identically, Daw et al. (2011) concluded that people benefited from ecosystem services constrained by the family size, education level, poverty, vulnerability, and social relations. These findings are also appropriate for hydrological ecosystem services. Therefore, the study on regional hydrological ecosystem services instead of hydrological ecosystem services could offer more useful information for integrated water resources management.

\subsection{Positive effect of the changes of regional hydrological ecosystem services on human well-being}

Human receives abundant benefits from natural environment in the form of goods and services (Tilman, 2000). Hydrological ecosystem services, derived from ecosystem services, involve provisioning services (e.g. water supply, power production and irrigation), regulating services (e.g. water purification and erosion control), water related cultural services (e.g. aesthetic appreciation and spiritual uses), water-related supporting services (e.g. provision of water for plant growth, create habitats for aquatic organisms) (Brauman et al., 2007). The positive effects of regional hydrological ecosystem services on human well-being are demonstrated from four aspects. Firstly, water supply considered as a provisioning service, both its quality and quantity are bound up with agricultural advance, economic development and human health. In the last 50 years, the amount of global water use has been tripled (Bennear and Olmstead, 2008). The FAO distinguishes freshwater consumption from the following aspects. According to the global average data, approximately $70 \%$ of water use is for agriculture, $20 \%$ for industrial and $10 \%$ for domestic purposes, including households, municipalities, commercial establishments and public services (Gleick and Ajami, 2014). Secondly, regulating services provided by regional hydrological ecosystem services are amongst the most essential for the sustainability of resource use. In Lake Victoria, Simonit and Perrings (2011) calculated the value of regulating services-nutrient buffering functions of wetland to improve the ecosystem service compensation scheme, indicated that the total cost of the payments for nutrient buffering services is 3.86 M dollars per year. Jenkins et al. (2010) emphasized the significance of the regulating services of wetland in the Mississippi Alluvial Valley for advising the government to take conservation practices on wetland ecosystem services (Faulkner et al., 2011). Thirdly, cultural services involved not only the visual enjoyment provided by the hydrological landscape, but also elevating the utility of human. Vemuri and Costanza (2006) and Engelbrecht (2009) stated that there was a positive correlation between service value of ecosystem per person and life satisfaction including hydrological ecosystem services. Fourthly, Vorosmarty et al. concluded that terrestrial water cycle is of critical importance to a wide array of earth system processes (Vörösmarty et al., 1998).

\subsection{Negative effect of the changes of regional hydrological ecosystem services on human well-being}

That human gain from hydrological ecosystem services is growing in a non-linear way. It implies that people will mutually develop with hydrological ecosystem if they obtain benefits in a proper range, or the hydrological ecosystem will be damaged if they blindly input labor and capitals. In verse, human well-being will be impaired by these damages (Wei et al., 2006; Eggen and Suter, 2007). Foley et al. (2005) proposed that the development of agriculture was at the expense of sacrificing natural ecosystems.

Assessment report of MA program in 2005 declared that $60 \%$ of the world's ecosystem services have been degraded, especially the services for providing fish, freshwater, and cultural services of spiritual and aesthetic value (Van Kamp et al., 2003). By contrast, the decline of hydrological ecosystem interferes the balance of other ecosystems and negatively affects the human well-being. Huber Sannwald et al. (2006) concluded that water scarcity and land degradation interacted with each other formed a vicious circle. Tisdell (2001) also stated that water scarcity affected the natural flow, thus IWRM needed to take water supply for natural flow into account. In summary, the decline of provisioning services of hydrological ecosystem is also the drivers of the degradation of other ecosystems.

Human well-being varies with the decline of hydrological supporting services which especially has a negative effect on the biodiversity conservation. The research on the relationship between vegetation dynamics and landscape pattern of desert-oasis reveals that the disappearance of scrub meadow, mire vegetation, and riparian forest leads to the decline of hydrological supporting services (Zhao et al., 2003), and in turn influences biodiversity and causes landscape to be deserted. Besides, Young and Potter (2002) proposed that the changes of water flow owing to estuarine sandbar strongly influenced the species and density of estuarine organisms based on the research on the normally-closed Wellstead Estuary on the south coast of Western Australia.

Regulating services of hydrological ecosystem reflect in the aspects of water and soil conservation and water purification. These services decline along with the decreasing of flood land or wetland, which leads to the degradation of purification capacity and surface water quality, thus influences residential water. Renard and Ferreira (1993) stated that sediment in rivers and reservoirs and soil erosion influenced and decided surface water quality. Besides, hydrological cultural services act on spiritual welfare of human. Liu et al. (2005) analyzed the changes of hydrological ecosystem services and found that the increasing area of reservoir pond in Sangong river basin improves flood control ability and enhances the provision services for production and living, but weakens aesthetic. 


\section{Preservation of regional hydrological ecosystem services for IWRM}

\subsection{Ecological civilization construction and preservation of regional hydrological ecosystem services}

Based on the above analysis, promoting the land use pattern creates a new thought for preserving regional hydrological ecosystem services and give more information for IWRM. With the concept of ecological civilization construction put forward, government invested a lot to build ecological programs by improving the way of land use for sustaining the law of the nature. For examples, The Grain for Green project covering the whole China makes for incorporating hillslope hydrology and adjusting regional runoff (Band et al., 1993), and the programs like Natural Forest Protection Project, the construction of Three-North Shelterbelt project, ecological protection zone playing the same role in hydrology. In addition, the program returning cultivated land to lakes benefits the water supply for regional hydrological ecosystem services. However, ecological measures sometimes incur more threatening hydrological problems when they are not matched well with regional hydrological ecosystem. As we all know, while water hyacinth was proved that it can be treated as a biosorbent to remove heavy metals or plant nutrients from polluted water for water purification (Ibrahim et al., 2012), it is also one of the world's worst aquatic weeds caused severe bio-invasion (Villamagna and Murphy, 2010).

\subsection{Urbanization and protection of hydrological ecosystem services}

A series of research shows that hydrological ecosystem services relate closely with urbanization, which may have a positive or negative impact on hydrological ecosystem services. Urbanization incurs a series of eco-hydrological problems, such as pumping groundwater exceedingly, land sinking cracking, rain flood disaster, the serious pollution of surface water, ect. Urbanization strongly interferes the environment security. To some extent, it makes the water environment worse, and hurts sustainability of urban civilization. In African, urbanization has reduced rainfall and the degree of harmony between ecosystem and urbanization (Annez et al., 2010). The development of urbanization is related to population migration, and large-scale agricultural population migration and land reform lead to hydrological ecosystem changes (Todes et al., 2010). However, some research shows that urbanization also has a positive impact on hydrological ecosystem services. Deng et al. have stated that urbanization promoted the water use and land use intensity (Deng et al., 2015). The proper pace of urbanization is the premise for ecosystem services' protection, sustainable economic advances and improvement of living standard. Therefore, it is vital for ecological safety to formulate reasonable land use policy and protect the ecological land (Jin et al., 2014).

\subsection{Ecological function regionalization and optimization of the integrated water resources management}

Spatial zoning is extensively applied in the field of geography with the development of theory and methodology of geography, and scholars have already made some achievements in application, such as agricultural zoning (Marin, 2007), woodland partition (Zollner et al., 2005), ecological zoning (Kara and Guler, 2007), and water resource partition (Shitikov et al., 2007). Regional spatial function zoning is an approach to analyze spatial geographical heterogeneity in the term of micro scale, aiming at making full use of the natural geographical system and preserving attributes of different regional functions, while ecological function regionalization identifies effectively different ecosystem services. Thus, it can refer a technique to study the core hydrological ecosystem services and their differential features and also they can be regulated to achieve the goal of gaining human well-being and optimizing the IWRM. As LUCC change the function and structure of hydrological ecosystem, people can optimize the way of land use to create a virtuous circle of society-ecosystem-economy (Metzger et al., 2006; Watanabe and Ortega, 2014). In the middle of the Heihe River Basin of China, Shi et al. (2014a,b) has analyzed the changes of hydrological ecosystem services through ecological function regionalization using System for Identifying and Zoning Ecosystem Services (SIZES). The results have revealed that with the decrease of forestry land, grassland, and wetland and the increase of urban land, the climate changes distinctly, provisioning services and regulating services of hydrological ecosystem should be emphasized conserved. Thus, ecosystem function regionalization conduces to discover the main ecological problems and develop a management system for supporting the development and protection of the hydrological ecosystem services, thus reach the target for optimizing the hydrological ecosystem function, IWRM and improving human well-being.

\section{Conclusion and discussion}

\subsection{Conclusions}

The process of land use change is complex and uncertain as its driving mechanism presents entirely disparate in different scales. With population growth, economic development and urbanization, proper land use pattern for sustainable development has been attracted concerns of ecologists, economists and management scientists. Combining research on land use changes and ecosystem services offers luxuriant evidences for settling regional environmental issues. The above analysis proved that land use changes thoroughly influence the regional hydrological ecosystem services through altering physical characters of earth's surface and water cycle processes.

Subsequently, the changes of the regional hydrological ecosystem services may positively or negatively act on human wellbeing considering their regional features. But to what extent do the regional hydrological ecosystem services influence human wellbeing? Notably, there are few quantitative analysis while most of relevant researches are concentrated on the descriptive analysis. Therefore, this is still a potential field of modeling and statistical methods for quantifying their impacts based on further understanding of the interaction of regional hydrological ecosystem service and human well-being.

However, the regional hydrological ecosystem services are highly sensitive to the changes of themselves. For the provisioning services, regulating services, cultural services and supporting services, we have always modified the supply of regional hydrological ecosystem services to enhance the delivery or production of a particular good or service. But the inappropriate distribution of the four services results in the strengthening of the provisioning services, whereas the other three are weakened, and in turn cause the overall decline of human well-being.

\subsection{Discussion}

While a large number of current studies emphasized the direct effects of human activities on hydrological ecosystem services, the analysis upon indirect effects induced by land use changes was still potential for further research. The review proceeded from disclosing the driving mechanism of LUCC and separately described how the four kinds of services of hydrology vary with LUCC, which 
clearly illustrated the processes of the generation of the indirect impacts. Therefore, the further research is required to assess the indirect impacts in each sector in the context of land use change, and the concept of these indirect effects into the development of society-economy-ecology for clarifying the process among LUCC, regional hydrological ecosystem services and human well-being, and integrated water resources management.

The intricate interaction processes among LUCC, regional hydrological ecosystem services and human well-being is dynamic. The consequences of competition among four services of hydrological ecosystem impair human well-being, which is opposite to their synergies, in premise of the whole system sustains its balance all the time to operate well. Just like people blindly pursuing provisioning services of hydrological ecosystem and ignoring the importance of others, which caused the inappropriate distribution of these services and decreased the overall benefits of the regional hydrological ecosystem services. Therefore, human should have a global and long-term perspective in the process of receiving goods and services from hydrological ecosystem services.

Human well-being and social system are inseparable, corresponding management system should support the coordinated development of land use, regional hydrological ecosystem services and human welfare. IWRM offers solutions to the water crisis in linking water to other vital resources and viewing the whole water cycle together with human interventions as the basis for sustainable water management. The research on the effects of land use changes on regional hydrological ecosystem services is in accordance with the purpose of the IWRM, affording valuable information for optimizing the IWRM. In the future, we can require deepgoing research from three aspects. First of all, we should focus on the quantitative relation between regional hydrological ecosystem services and human well-being. Secondly, it's important to analyze the mechanism about IWRM under the different background of land use policy. Thirdly, it's necessary to study on comprehensive function regionalization of regional water resources.

\section{Conflicts of interest}

The authors declare that there is no conflict of interests regarding the publication of this paper.

\section{Acknowledgments}

This research was financially supported by the National Scientific Foundation of China (Grant No. 41171434), the National Natural Science Funds of China for Distinguished Young Scholar Project (Grant No. 71225005), the National Natural Science Foundation of China (Grant no. 41501593) and Exploratory Forefront Project for the Strategic Science Plan in IGSNRR, CAS (Y2V2029).

\section{References}

Annez, P., Buckley, R., Kalarickal, J., 2010. African urbanization as flight? some policy implications of geography. Urban Forum 21 (3), 221-234.

Bakker, K., 2012. Water security: research challenges and opportunities. Science 337 (6097), 914-915.

Band, L.E., Patterson, P., Nemani, R., Running, S.W., 1993. Forest ecosystem processes at the watershed scale: incorporating hillslope hydrology. Agric. For. Meteorol. 63 (1), 93-126.

Bennear, L., Olmstead, S., 2008. The impacts of the "right to know": information disclosure and the violation of drinking water standards. J. Environ. Econ. Manag. 56 (2), 117-130.

Bennett, E.M., Carpenter, S.R., Caraco, N.F., 2001. Human impact on erodable phosphorus and eutrophication: a global perspective increasing accumulation of phosphorus in soil threatens rivers, lakes, and coastal oceans with eutrophication. BioScience 51 (3), 227-234.

Bolund, P., Hunhammar, S., 1999. Ecosystem services in urban areas. Ecol. Econ. 29 (2), 293-301.
Brauman, K.A., Daily, G.C., Duarte, T.K.E., Mooney, H.A., 2007. The nature and value of ecosystem services: an overview highlighting hydrologic services. Environ. Resour. 32, 67-98.

Calizaya, A., Meixner, O., Bengtsson, L., Berndtsson, R., 2010. Multi-criteria decision analysis (MCDA) for integrated water resources management (IWRM) in the lake Poopo basin, Bolivia. Water Resour. Manag. 24 (10), 2267-2289.

Carpenter, S.R., Caraco, N.F., Correll, D.L., Howarth, R.W., Sharpley, A.N., Smith, V.H., 1998. Nonpoint pollution of surface waters with phosphorus and nitrogen. Ecol. Appl. 8 (3), 559-568.

Crow, T.R., Host, G.E., Mladenoff, D.J., 1999. Ownership and ecosystem as sources of spatial heterogeneity in a forested landscape, Wisconsin, USA. Landsc. Ecol. 14 (5), 449-463.

Daily, G.C., Matson, P.A., 2008. Ecosystem services: from theory to implementation. Proc. Natl. Acad. Sci. 105 (28), 9455-9456.

Daw, T., Brown, K., Rosendo, S., Pomeroy, R., 2011. Applying the ecosystem services concept to poverty alleviation: the need to disaggregate human well-being. Environ. Conserv. 38 (04), 370-379.

Delgado, L.E., Sepúlveda, M.B., Marín, V.H., 2013. Provision of ecosystem services by the Aysén watershed, Chilean Patagonia, to rural households. Ecosyst. Serv. 5, 102-109.

Deng, X., Su, H., Zhan, J., 2008. Integration of multiple data sources to simulate the dynamics of land systems. Sensors 8 (2), 620-634.

Deng, X., Jiang, Q., Zhan, J., He, S., Lin, Y., 2010. Simulation on the dynamics of forest area changes in Northeast China. J. Geogr. Sci. 20 (4), 495-509.

Deng, X., Huang, J., Rozelle, S., Zhang, J., Li, Z., 2015. Impact of urbanization on cultivated land changes in China. Land Use Policy 45, 1-7.

Deng, X., Li, Z., Huang, J., Shi, Q., Li, Y., 2013a. A revisit to the impacts of land use changes on the human wellbeing via altering the ecosystem provisioning services. Adv. Meteorol. 1-8. http://www.hindawi.com/journals/amete/2013/ 907367/, [Article ID 907367].

Deng, X., Zhao, C., Yan, H., 2013b. Systematic modeling of impacts of land use and land cover changes on regional climate: a review. Adv. Meteorol. 1-11. http:// www.hindawi.com/journals/amete/2013/317678/, [Article ID 317678].

Deng, X., Zhao, C., Lin, Y., Zhang, T., Qu, Y., Zhang, F., Wang, Z., Wu, F., 2014. Downscaling the impacts of large-scale LUCC on surface temperature along with IPCC RCPs: a global perspective. Energies 7 (4), 2720-2739.

Dimitriou, E., Zacharias, I., 2010. Identifying microclimatic, hydrologic and land use impacts on a protected wetland area by using statistical models and GIS techniques. Math. Comput. Model. 51 (3), 200-205.

Eggen, R.I., Suter, M.J.F., 2007. Analytical chemistry and ecotoxicology-Tasks, needs and trends. J. Toxicol. Environ. Health Part A 70 (9), 724-726.

Engelbrecht, H.J., 2009. Natural capital, subjective well-being, and the new welfare economics of sustainability: some evidence from cross-country regressions. Ecol. Econ. 69 (2), 380-388.

Faulkner, S., Barrow Jr., W., Keeland, B., Walls, S., Telesco, D., 2011. Effects of conservation practices on wetland ecosystem services in the Mississippi Alluvia Valley. Ecol. Appl. 21, 31-48.

Foley, J.A., DeFries, R., Asner, G.P., Barford, C., Bonan, G., Carpenter, S.R. Snyder, P.K., 2005. Global consequences of land use. Science 309 (5734), $570-574$.

Gascoigne, W.R., Hoag, D., Koontz, L., Tangen, B.A., Shaffer, T.L., Gleason, R.A., 2011 Valuing ecosystem and economic services across land-use scenarios in the Prairie Pothole Region of the Dakotas, USA. Ecol. Econ. 70 (10), 1715-1725.

Gleick, P.H., Ajami, N., 2014. The World's Water Volume 8: The Biennial Report on Freshwater Resources, vol. 8. Island Press.

Huang, J., Zhu, L., Deng, X., 2007. Regional differences and determinants of built-up area expansion in China. Sci. China Ser. D Earth Sci. 50 (12), 1835-1843.

Huber Sannwald, E., Maestre, F.T., Herrick, J.E., Reynolds, J.F., 2006. Ecohydrological feedbacks and linkages associated with land degradation: a case study from Mexico. Hydrol. Process. 20 (15), 3395-3411.

Ibrahim, H.S., Ammar, N.S., Soylak, M., Ibrahim, M., 2012. Removal of Cd (II) and Pb (II) from aqueous solution using dried water hyacinth as a biosorbent. Spectrochim. Acta 96, 413-420.

Jenkins, W., Murray, B., Kramer, R., Faulkner, S., 2010. Valuing ecosystem services from wetlands restoration in the Mississippi Alluvial Valley. Ecol. Econ. 69 (5) $1051-1061$.

Jin, Q., Deng, X., Wang, Z., Shi, C., Li, X., 2014. Analysis and projection of the relationship between industrial structure and land use structure in China. Sustainability 6 (12), 9343-9370.

Kara, T., Guler, M., 2007. Agro-ecological zoning by GIS: a case study of the Bafra and Carsamba plains in Turkey. Asian J. Chem. 19 (3), 2277-2284.

Kremen, C., Niles, J.O., Dalton, M.G., Daily, G.C., Ehrlich, P.R., Fay, J.P., ..., Guillery, R.P. 2000. Economic incentives for rain forest conservation across scales. Science 288 (5472), 1828-1832.

Lambin, E.F., Turner, B.L., Geist, H.J., Agbola, S.B., Angelsen, A., Bruce, J.W., .... Xu, J., 2001. The causes of land-use and land-cover change: moving beyond the myths. Glob. Environ. Change 11 (4), 261-269.

Lambin, E.F., Geist, H.J., 2001. Global land-use and land-cover change: what have we learned so far. Glob. Change Newsl. 46 (6), 27-30.

Liu, L., Xia, J., Feng, H., Zhan, C., Yin, C., 2005. The driving forces of the aquatic ecosystem services function-A case of Sangonghe watershed. Arid. Land Geogr 28 (3), 347-351.

Li, M., Wu, J., Deng, X., 2013. Identifying drivers of land use change in China: a spatial multinomial logit model analysis. Land Econ. 89 (4), 632-654. 
Lin, D., Lin, Y., 2014. Stakeholders of voluntary forest carbon offset projects in China: an empirical analysis. Adv. Meteorol. 1-7. http://www.hindawi.com/journals/ amete/2015/518698/, [Article ID 518698].

Lin, Y., Deng, X., Li, X., Ma, E., 2014. Comparison of multinomial logistic regression and logistic regression: which is more efficient in allocating land use? Front. Earth Sci. 8 (4), 512-523.

Liu, J., Kuang, W., Zhang, Z., Xu, X., Qin, Y., Ning, J., Chi, W., 2014. Spatiotemporal characteristics, patterns, and causes of land-use changes in China since the late 1980s. J. Geogr. Sci. 24 (2), 195-210.

Marin, M.C., 2007. Impacts of urban growth boundary versus exclusive farm use zoning on agricultural land uses. Urban Aff. Rev. 43 (2), 199-220.

McConnell, W.J., 2002. Madagascar: emerald isle or paradise lost? Environ. Sci. Policy Sustain. Dev. 44 (8), 10-22.

Metzger, M.J., Rounsevell, M.D.A., Acosta-Michlik, L., Leemans, R., Schröter, D., 2006. The vulnerability of ecosystem services to land use change. Agric. Ecosyst. Environ. 114 (1), 69-85.

Millette, T.L., Tuladhar, A.R., Kasperson, R.E., Turner, L.B., 1995. The use and limits of remote sensing for analysing environmental and social change in the Himalayan Middle Mountains of Nepal. Glob. Environ. Change 5 (4), 367-380.

Murray, K.S., Rogers, D.T., 1999. Groundwater vulnerability, brownfield redevelopment and land use planning. J. Environ. Plan. Manag. 42 (6), 801-810.

Naveh, Z., 1995. Interactions of landscapes and cultures. Landsc. Urban Plan. 32 (1), 43-54.

Oleson, K.L., Barnes, M., Brander, L.M., Oliver, T.A., Van Beek, I., Zafindrasilivonona, B., Van Beukering, P., 2015. Cultural bequest values for ecosystem service flows among indigenous fishers: a discrete choice experiment validated with mixed methods. Ecol. Econ. 114, 104-116.

Pejchar, L., Mooney, H.A., 2009. Invasive species, ecosystem services and human well-being. Trends Ecol. Evol. 24 (9), 497-504.

Peterson, G.D., Beard Jr., T.D., Beisner, B.E., Bennett, E.M., Carpenter, S.R., Cumming, G.S., ..., Havlicek, T.D., 2003. Assessing future ecosystem services: a case study of the Northern Highlands Lake District, Wisconsin. Conserv. Ecol. 7 (3), 1.

Pleasant, M.M., Gray, S.A., Lepczyk, C., Fernandes, A., Hunter, N., Ford, D., 2014. Managing cultural ecosystem services. Ecosyst. Serv. 8, 141-147.

Polasky, S., Segerson, K., 2009. Integrating ecology and economics in the study of ecosystem services: some lessons learned. Resource 1409-1434.

Renard, K.G., Ferreira, V.A., 1993. RUSLE model description and database sensitivity. J. Environ. Qual. 22 (3), 458-466.

Rockstrom, J., 2000. Water resources management in smallholder farms in Eastern and Southern Africa: an overview. Phys. Chem. Earth 25 (3), 275-283.

Shi, C., Zhan, J., Yuan, Y., Wu, F., Li, Z., 2014a. Land use zoning for conserving ecosystem services under the impact of climate change: a case study in the middle reaches of the heihe river Basin. Adv. Meteorol. 1-13. http://www. hindawi.com/journals/amete/2015/496942/, [Article ID 496942].

Schindler, D.W., Donahue, W.F., 2006. An impending water crisis in Canada's western prairie provinces. Proc. Natl. Acad. Sci. 103 (19), 7210-7216.

Shi, Q., Chen, S., Shi, C., Wang, Z., Deng, X., 2014b. The impact of industrial transformation on water use efficiency in Northwest region of China. Sustainability 7 (1), 56-74.

Shitikov, V.K., Vykhristyuk, L.A., Pautova, V.N., Zinchenko, T.D., 2007. Comprehensive ecological zoning of the Kuibyshev Reservoir. Water Resour. 34 (4), 450-458.

Simonit, S., Perrings, C., 2011. Sustainability and the value of the 'regulating'services: wetlands and water quality in Lake Victoria. Ecol. Econ. 70 (6), 1189-1199.

Singh, R.B., Shi, C., 2014. Advances in observation and estimation of land use impacts on climate changes: improved data, upgraded models, and case studies. Adv. Meteorol. 1-7. http://www.hindawi.com/journals/amete/2014/748169/, [Article ID 748169].

Smaling, E.M.A., Fresco, L.O., 1993. A decision-support model for monitoring nutrient balances under agricultural land use (NUTMON). Geoderma 60 (1), 235-256.

Smith, L.M., Case, J.L., Smith, H.M., Harwell, L.C., Summers, J.K., 2013. Relating ecoystem services to domains of human well-being: foundation for a US index. Ecol. Indic. 28, 79-90.
Smith, M., De Groot, D., Perrot-Maître, D., Bergkamp, G., 2006. Pay-establishing Payments for Watershed Services.

Tilman, D., 2000. Causes, consequences and ethics of biodiversity. Nature 405 (6783), 208-211.

Tisdell, J.G., 2001. The environmental impact of water markets: an Australian casestudy. J. Environ. Manag. 62 (1), 113-120.

Todes, A., Kok, P., Wentzel, M., Van Zyl, J., Cross, C., 2010. Contemporary south african urbanization dynamics. Urban Forum 21 (3), 331-348.

Tognetti, S.S., Aylward, B., Mendoza, G., 2006. Markets for watershed services. Encycl. Hydrol. Sci. 193. John Wiley \& Sons, Ltd Press.

Townsend, A.R., Howarth, R.W., Bazzaz, F.A., Booth, M.S., Cleveland, C.C., Collinge, S.K., ..., Wolfe, A.H., 2003. Human health effects of a changing global nitrogen cycle. Front. Ecol. Environ. 1 (5), 240-246.

Turner, B.L., Lambin, E.F., Reenberg, A., 2007. The emergence of land change science for global environmental change and sustainability. Proc. Natl. Acad. Sci. 104 (52), 20666-20671.

UN, 1992. The Dublin statement on water and sustainable development. In: Guiding Principles. Inter-nation Conference on Water and the Environment (ICWE) in Dubin.

Van Kamp, I., Leidelmeijer, K., Marsman, G., De Hollander, A., 2003. Urban environmental quality and human well-being: towards a conceptual framework and demarcation of concepts; a literature study. Landsc. Urban Plan. 65 (1), 5-18.

Veldkamp, A., Verburg, P.H., 2004. Modelling land use change and environmental impact. J. Environ. Manag. 72 (1), 1-3.

Vemuri, A.W., Costanza, R., 2006. The role of human, social, built, and natural capital in explaining life satisfaction at the country level: toward a National Well-Being Index (NWI). Ecol. Econ. 58 (1), 119-133.

Villamagna, A.M., Murphy, B.R., 2010. Ecological and socio-economic impacts of invasive water hyacinth (Eichhornia crassipes): a review. Freshw. Biol. 55 (2), 282-298.

Vörösmarty, C.J., Federer, C.A., Schloss, A.L., 1998. Potential evaporation functions compared on US watersheds: possible implications for global-scale water balance and terrestrial ecosystem modeling. J. Hydrol. 207 (3), 147-169.

Watanabe, M.D., Ortega, E., 2014. Dynamic emergy accounting of water and carbon ecosystem services: a model to simulate the impacts of land-use change. Ecol. Model. 271, 113-131.

Weng, Q., 2002. Land use change analysis in the Zhujiang Delta of China using satellite remote sensing, GIS and stochastic modelling. J. Environ. Manag. 64 (3), 273-284.

Wei, D. Kisuno, A., Kameya, T, Urano, K., 2006. A new method for evaluating biological safety of environmental water with algae, daphnia and fish toxicity ranks. Sci. Total Environ. 371 (1), 383-390.

Wu, F., Zhan, J., Yan, H., Shi, C., Huang, J., 2013. Land cover mapping based on multisource spatial data mining approach for climate simulation: a case study in the farming-pastoral ecotone of North China. Adv. Meteorol. 1-12. http:// www.hindawi.com/journals/amete/2013/520803/, [Article ID 520803].

Wu, F., Zhan, J., Su, H., Yan, H., Ma, E., 2014. Scenario-based impact assessment of land Use/Coverand climate changes on watershed hydrology in heihe river Basin of Northwest China. Adv. Meteorol. 1-11. http://www.hindawi.com/ journals/amete/2015/410198/, [Article ID 410198].

Xu, Q., Jiang, Q., Cao, K., Li, X., Deng, X., 2013. Scenario-based analysis on the structural change of land uses in China. Adv. Meteorol. 1-12. http://www. hindawi.com/journals/amete/2013/919013/, [Article ID 919013].

Young, G.C., Potter, I.C., 2002. Influence of exceptionally high salinities, marked variations in freshwater discharge and opening of estuary mouth on the characteristics of the ichthyofauna of a normally-closed estuary. Estuar. Coast. Shelf Sci. 55 (2), 223-246.

Zhao, C.Y., Wang, Y.C., Li, Z.L., Li, G.Z., 2003. Study on the relationship between vegetation dynamics and landscape pattern of desert oasis-a casestudy of Sangong River basin, Xinjiang. Arid. Land Geogr. 26 (4), 297-304.

Zhen, L., Deng, X., Wei, Y., Jiang, Q., Lin, Y., Helming, K., Hu, J., 2014. Future land use and food security scenarios for the Guyuan district of remote western China. iFor. Biogeosci. For. 7 (6), 372.

Zollner, P.A., Gustafson, E.J., He, H.S., Radeloff, V.C., Mladenoff, D.J., 2005. Modeling the influence of dynamic zoning of forest harvesting on ecological succession in a northern hardwoods landscape. Environ. Manag. 35 (4), 410-425. 